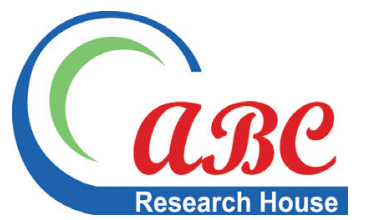

Access this article online

Website:

www.ajtp.us

Volume 1

Number 1/2014

Issue 1

DOI:

Licenced:

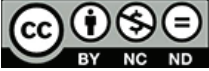

E-mail for correspondence: taposhknru_bd@yahoo.

com

Received: May 29, 2014

Accepted: June 12, 2014

Published: June 30, 2014

\section{Variations in Opinions toward Disclosure Trend of Insurance Companies in Bangladesh: An Empirical Study}

\author{
Md. Abu Bokar Siddique', Taposh Kumar Neogy², Md. Rabiul Islam ${ }^{3}$ \\ ${ }^{1}$ Associate Professor in Accounting, Department of Humanities, Rajshahi University of Engineering \& \\ Technology, Rajshahi, Bangladesh, \\ ${ }^{2}$ Assistant Professor in Accounting, Institute of Business Administration (IBA), (Under National \\ University), Rajshahi, Bangladesh, \\ ${ }^{3}$ Lecturer in Management, Department of Humanities, Rajshahi University of Engineering \& \\ Technology, Rajshahi, Bangladesh
}

\begin{abstract}
The study is an attempt to examine empirically the perceptions of a sample of users of reported information regarding the use of annual reports for decision making, adequacy, reliability, consistency, comparability, relevance, satisfaction and compliance of BASs (IASs) in preparing annual report. Results of the study demonstrated that there is a lack of disclosure in the annual reports of insurance companies. The study also found insignificant variations in opinions towards adequacy, consistency, relevance, satisfaction and compliance of provisions of Bangladesh Accounting Standards in disclosure policy of the companies while there are significant variations in responses regarding reliability and comparability of accounting information disclosed in the annual reports. Insurance companies should develop their reporting policy to satisfy their users through compliance the disclosure requirements of international standards.
\end{abstract}

Keywords: Financial disclosure, Insurance company, Bangladesh

\section{Introduction}

Knowledge of the overall extent of corporate annual financial report disclosure is necessary to pursue national accounting development. The primary objective of this study is to investigate the perception of users regarding the availability, adequacy, and usefulness of information disclosed in the financial reports of insurance companies listed on the Dhaka stock Exchange. Accounting is an information system and its primary goal is to communicate reliable financial information to management, owner(s) and outsiders. Financial information which is used only within the company as a basis for decisionmaking is referred to as internal information and the financial information which is used by outsiders is called the external information. For reporting external information, however, specific reports commonly referred to as Balance Sheet and
Income Statement have been developed. Financial statements are external reports which communicate financial information to the outsiders. Although the need for external information to the users and the form of these statements may also vary among different business units, the standard format is generally the same. Proper disclosure of relevant information in the financial statements of a company is of great importance since the members of the company as well as other parties, make most of their appraisals and decisions regarding the company on the basis of such statements. Annual financial statements should, therefore, disclose relevant information clearly and accurately. "The ultimate objective of disclosure is to communicate timely, reliable, and material information which is useful to the users of annual reports in an intelligible form" (R.K. Agarwal, 1995). Different user groups (internal \& external) have different objective in using financial reports. External users use financial

This article is licensed under a Creative Commons Attribution-NonCommercial-NoDerivatives 4.0 International License. 
reports some common interest. The aim of the study is to seeking the opinions of the respondents groups that expected to disclose in the annual reports.

\section{Need for the Study}

Disclosure and reporting in Insurance sector of Bangladesh are not only inadequate but also biased and misleading. In most of the cases, financial statements of the local Insurance are dressed up and cosmetised with outdated legal framework and poor performance of the accounting profession significantly contributed to this undesirable situation. Although the financial reporting of the insurance companies in Bangladesh is mainly influenced by the Insurance Act, 2008, this legislation does not clearly specify the accounting policies to be followed and disclosed. However, professional requirements are there in Bangladesh for making general disclosure of accounting policies. For the same purpose, Institute of Chartered Accountants of Bangladesh (ICAB) has adopted the International Accounting Standard-1 (IAS-1), Disclosures of Accounting Policies and the Institute of Cost and Management Accountants of Bangladesh (ICMAB) has issued a pronouncement, Statement of Standard Accounting Practice-2 (SSAP-2), Determination and Disclosure of Accounting Policies. The present study strives to evaluate the disclosure practices of insurance companies in the annual reports in Bangladesh in the light of the relevant reporting requirements regarding the perceptions of users.

\section{Objectives of the Study}

Financial reporting is a means to provide information to the interested parties to help them in making business and economic decisions. The economic, legal, political and social environment of any enterprise is affected by such reporting. Therefore, the main objective of the study is to focus the perception of the investors and professional accountants as users about their perceived importance for various sources of information in making their decisions and their opinions regarding the qualitative characteristics of accounting information of the corporate annul reports in the insurance sector in Bangladesh. The specific objectives of the study are:

i. To analyze the compliance of BASs and Insurance Act in corporate financial disclosures.

ii. To know the selected respondent's attitude towards qualitative characteristics of the financial disclosure in the annual reports.

iii. Recommending some measures to take a sound corporate financial report.

\section{Review of Related Literatures}

There are studies of Wallace (1988a) in Nigeria and Nicholls and Ahmed (1995) in Bangladesh, which measured the quality of disclosure taking into consideration the perception of users in a developing country perspective. In an article Buzby (1974) presented the results of a mailed questionnaire survey of financial analysts which sought to determine the relative importance of 38 selected items information. The results indicated that many of the items were adequately disclosed in the sample at that the correlation between the relative importance of the items and the extent their disclosure was small. On the basis these results, the writer has conclude that an opportunity exists for an expansion of the extent of disclosure in the annual reports of small and medium companies. Anura \& Kathy in an article used a questionnaire survey covering seven user groups (e.g., Accountants, executives, bankers, tax officers, academics, financial analysts, and investors). The results reveal that most use annual reports for obtaining information of share transaction. The paper also reveals that in comparison with developed market Sri-Lankan users depends more on annual report information than on information provided by stock brokers, newspapers, and other media reviews. Anderson (1981) has focused the importance of perception of investors. He found that the desire of external users for additional information to be provided in the corporate annul reports. Anderson and Epstein (1995) argued that the annual corporate reports came third, after stockbroker's advice and financial newspapers \& magazines as a basis for investment decision of Australian individual investors. Nevertheless, the majority of their respondents (72\%) perceived annual corporate reports to be of only moderate use. They also highlight the Australian investors' demand for additional disclosures in the annual reports. Abu Nassar and Rutherford (1996) have discovered the view of external users like shareholders, bank loan officers, stockbrokers and academicians in the corporate annual reports. They said that income statement and balance sheet to be the most widely read part of the annual reports by all the users. Ali et.al. (2008) focused the attitudes of individual respondents on various aspects of corporate annual reports in Bangladesh. They found that the current disclosures of the corporate annual reports are not adequate in evaluating the goal of corporate governance. The researcher thinks that user should be contacted frequently to assess their perceptions about various aspects of reporting practices of public companies since their views will provide the main feedback to improve the communication function of corporate annual reports.

\section{Regulatory Framework}

Different user groups like internal users and external users used corporate financial information different purposes. Information is data that has been processed into a form that is meaningful to the recipient and is of real or perceived value in current or prospective actions or decisions. Financial information which is used only within the company as a basis for decision-making is referred to as internal information and the financial information which is used by outsiders is called the external information.

There are two main users groups like internal users and external users. Internal users include managers and employees rather than manager while external users involve investors, union of employees, lenders, customers, suppliers, social responsibility groups, competitors and government.

Internal users need to review financial information about the company, such as financial statement information. They also use non-financial information about the company, such as customer satisfaction levels and competitor data. Financial accounting and management accountancy provide information to two different user groups. External users primarily rely on financial 
information about the company. They analyze this information in conjunction with general economic information, such as information about the industry in which the company as a whole. In addition, financial accounting only reports information on financial transactions that have occurred in the past.

Before the needs of users can be considered, it is necessary to identify the users of business information, as different users utilize business information to satisfy different needs. There is general agreement that, before it can be regarded as useful in satisfying the needs of various user groups, accounting information should satisfy the following criteria:

\section{Understandability}

This implies the expression, with clarity, of accounting information in such a way that it will be understandable to users who are generally assumed to have a reasonable knowledge of business and economic activities.

\section{Relevance}

This implies that, to be useful, accounting information must assist a user to form, confirm or maybe revise a view - usually in the context of making a decision (e.g. should I invest, should I lend money to this business? Should I work for this business?).

\section{Consistency}

This implies consistent treatment of similar items and application of accounting policies. If accrual basis is followed in certain year, cash basis should not be followed in the next year.

\section{Objectivity}

This implies that accounting information is prepared and reported in a neutral way. In other words, it is not biased towards a particular user group or vested interest.

\section{Comparability}

This implies the ability for users to be able to compare similar companies in the same industry group and to make comparisons of performance over time. Much of the work that goes into setting accounting standards is based around the need for comparability.

\section{Reliability}

This implies that the accounting information that is presented is truthful, accurate, complete (nothing significant missed out) and capable of being verified (e.g. by a potential investor).

Corporate annual reports are primarily prepared for external users. Therefore such reports should be designed in form and content, according to the needs of external users.

\section{Methodology}

The study is based only on the primary data. The primary data are the opinions and ideas of the respondents, which have been collected through face to face interview by the researcher. Specific closed ended questionnaires have been prepared to collect the primary data required for the study.

It is necessary to prepare a questionnaire to collect information regarding the perception of various groups of users about the importance of the items of information in the annual reports of insurance company. To construct a questionnaire, items have been selected on the basis of importance. The researcher has prepared a structured questionnaire to collect opinion of the respondents about the quality of information disclosed in the annual reports, level of disclosure, compliance of accounting standards etc. The questionnaire has been divided into two parts (Buzby S.L., 1974). The first part includes some essential information of the respondents like their occupation, training $\&$ educational qualifications. The second part provides the items of information comprising disclosure in corporate annual reports. This study covers a sample of 40 investors (Businessmen $20 \&$ Academicians 20) and 20 professional accountants. The total number of respondents, therefore, is 60 . The respondents are requested to rate each item of information on a yes/no basis.

The study is based on opinions of the respondents. So, it is very important to know whether there are significant differences between the opinions of the respondents. Accordingly, we develop a null hypothesis as follows:

$\mathrm{H}_{0}$ : There are no significant differences in the opinions of the respondents.

In order to test whether there are significant differences between the opinions of the respondents, we conducted chi square test using SPSS.

\section{Results and Analysis}

Table No.-1: Opinions of the Respondents Regarding the use of Annual Reports for Decision Making

The user group of financial statement use annual reports for decision making. The respondents were asked to respond, whether they use annual reports for decision making. The opinions of the respondents are summarized in Table-1 (shown in Appendix), which shows that $87 \%$ of respondents use annual reports for decision making and the rests do not. In order to test whether there are significant differences in the opinions of the respondents, the researchers conducted chi-square test (shown in Appendix, Table-1.1), using SPSS. The value of chi-squire is 1.154 at 0.562 significant levels. Thus, the null hypothesis is accepted which means that there is no significant difference among the opinions of the respondents regarding the use of corporate annual reports for decision making.

Table No.-2: Opinions of the Respondents Regarding the Adequacy of Disclosure in Annual Reports

Under the questionnaire survey, the respondents were asked if they think that annual reports contain adequate information necessary to serve their purposes for using. The responses are 
summarized in Table 2 (shown in Appendix), which depicts that $53 \%$ of the respondents think that the annual reports of insurance companies are adequate while $47 \%$ of respondents think as inadequate. In order to test whether there are significant differences in the opinions of the respondents, chi-square test (shown in Appendix, Table-2.1), has been conducted. The value of chi-squire is 3.75 at .153 significant levels. Thus, the null hypothesis is accepted which means that there is no significant difference among the opinions of the respondents regarding the adequacy of disclosure in the corporate annual reports.

\section{Table No.-3: Opinions of the Respondents Regarding the Reliability of Information in Annual Reports}

Reliability of information is an important qualitative characteristic in the corporate annual reports. Keeping this point in view, in the questionnaire, the respondents were asked if they thought that annual reports contain reliability of information necessary to serve their purposes in uses. The responses are summarized in Table-3 (shown in Appendix), which shows that $68 \%$ of respondents think that the annual reports of insurance companies are reliable while $32 \%$ of respondents think that annual reports of insurance companies are not reliable. Chisquare test (shown in Appendix, Table-3.1), has been conducted to test whether there are any significant differences in the opinions of the respondents. The value of chi-square is 6.624 at .036 significant levels. Thus, the null hypothesis is rejected which means that there is significant difference in the opinions of the respondents regarding the reliability of disclosure in annual reports of insurance companies.

\section{Table No.-4: Opinions of the Respondents Regarding the Consistency of Information in Annual Reports}

Consistency of information is an important qualitative characteristic in corporate annual reports. Keeping this point in mind, in the questionnaire, the respondents were asked about consistency of annual reports. The responses are summarized in Table-4 (shown in Appendix), which portrays that $72 \%$ of respondents think that the annual reports of insurance companies are consistent while $28 \%$ of respondents think that annual reports of insurance companies are not consistent. In order to test whether there are significant differences in the opinions of the respondents, chi-square test (shown in Appendix, Table-4.1), has been conducted using SPSS. The value of chi-squire is 3.119 at .210 significant levels. Thus, the null hypothesis is accepted which means that there is no significant difference among the opinions of the respondents regarding the consistency of disclosure in the corporate annual reports.

Table No.-5: Opinions of the Respondents Regarding
the Comparability of Information's in Annual Reports

Comparability of information is also an important qualitative characteristic in the corporate annual reports. The respondents were asked to respond regarding the comparability of information in the annual reports of insurance companies. The responses are summarized in Table-5 (shown in Appendix), which shows that $70 \%$ of respondents think that the annual reports of insurance companies are comparable while $30 \%$ of respondents think that annual reports of insurance companies are not comparable. In order to test whether there are significant differences between the opinions of the respondents, chi-square test (shown in Appendix, Table-5.1) has been conducted. The value of chi-squire is 7.619 at .022 significant levels. Thus, the null hypothesis is rejected which means that there is significant difference in the opinions of the respondents regarding the comparability of disclosure in annual reports of insurance companies.

\section{Table No.-6: Opinions of the Respondents Regarding the Relevance of Information in Annual Reports}

The respondents were asked to respond regarding the Relevance of information in annual reports of insurance companies. The responses are summarized in Table-6 (shown in Appendix), which reveals that $72 \%$ of respondents think that the annual reports of insurance companies are relevant while $28 \%$ of respondents think that annual reports of insurance companies are not relevant. In order to test whether there are significant differences in the opinions of the respondents, the researchers conducted chi square test (shown in Appendix, Table-6.1). The value of chi-squire is 3.119 at .210 significant levels. Thus, the hypothesis is accepted which means that there is no significant difference in the opinions of the respondents regarding the relevance of disclosure in annual reports.

\section{Table No.-7: Opinions of the Respondents Regarding the Satisfaction of Information in Annual Reports}

The respondents were asked to respond regarding the satisfactory of information in annual reports of insurance companies. The responses are summarized in Table-7 (shown in Appendix), which delineates that $42 \%$ of respondents think that the disclosure of information in annual reports of insurance companies are satisfactory and the rests are not satisfactory. In order to test whether there are significant differences in the opinions of the respondents, the researchers conducted chi-square test (shown in Appendix, Table-7.1), using SPSS. The value of chi-squire is 0.960 at .619 significant levels. Thus, the null hypothesis is accepted which means that there is no significant difference in the opinions of the respondents regarding the satisfaction of disclosure in the corporate annual reports.

\section{Table No.-8: Opinions of the Respondents Regarding Compliance of BASs (IASs) to Preparing Annual Reports}

The respondents were asked to respond regarding the compliance of BASs in preparing annual reports of insurance companies. The responses are summarized in Table-8 (shown in Appendix), which reveals that $85 \%$ of the respondents think that insurance companies follow the BASs in preparing annual reports while $15 \%$ of respondents think that insurance companies do not follow the BASs. In order to test whether there are significant differences in the opinions of the respondents, the researchers 
conducted chi-square test (shown in Appendix, Table-8.1). The value of chi-squire is 5.49 at .064 significant levels. Thus, the null hypothesis is accepted which means that there is no significant difference among the opinions of the respondents regarding the compliance of BASs of disclosure in the corporate annual reports.

\section{Conclusion}

As per objectives of the study and testing of hypothesis it can be concluded that most of the respondents think that the information disclosed in the annual report is adequate $(53 \%)$, reliable $(68 \%)$, consistent $(72 \%)$, comparable $(70 \%)$, relevant (72\%), satisfactory (50\%) and compliance with BASs $(85 \%)$. Variations in opinions towards adequacy, consistency, relevance, satisfaction and compliance of provisions of BASs in disclosure policy of the companies are not significant while there are significant variations in responses regarding reliability and comparability of accounting information disclosed in annual reports of the sample Companies during the period under study. It is evident from the users perception that the disclosures of insurance companies are inadequate compared to the provisions prescribed in regulatory frame work like Insurance Companies Act 2008, Companies Act 1994, Securities Exchange Rules 1987 and Bangladesh Accounting Standard (BASs).

For better disclosure of insurance companies in their financial statement, the following points can be suggested:

Firstly, all the insurance companies should strictly follow the provisions of Insurance Companies Act 2008, Companies Act 1994, SEC rules, SEC notifications and IASs/IFRSs as adopted in Bangladesh.

Secondly, detailed notes to accounting policies need to be elaborated.
Finally, management attitude is very much important to disclose the available information in the financial statement such as if the attitude is conservative the financial disclosure will be less. However, it is the demand of time to disclose more information to satisfy the users. Only a sound financial reporting system with good governance can bring or maintain the confidence of the investors.

\section{References}

Abu Nassar and Rutherford (1996), "Corporate Disclosure Policy and Analyst Behavior in Jordan" The Accounting Review, (10) pp., 467-492

Agarwal R.K., (1995) "Disclosure in Company Account", Hind Law Publishers, Delhi, p-2

Anderson (1981), "The usefulness of Accounting and other Information Disclosed Corporate Annual Reports to Institutional Investors in Australia", Accounting and Business Research, pp. 259-265.

Anderson and Epstein (1995), "The Pricing of Audit Services: Further Evidence from the Canadian Market", Accounting and Business Research, volume 24 No.25 pp. 195-207.

Ali, Khan, Fatima and Masud (2008) "Voluntary Corporate Governance Reporting in Annual Reports: A Study of an MNC", ASA University Review Vol. 2 No.2 July-December, pp 61-75.

Auruna D.Z. and Kathy R. (2010) "An Investigation of perceptions of Company Annual Report Users in Srilanka", International Journal of Emerging Markets, vol. 5 No. 2, pp. 183-202.

Buzby, S. L. (1974) "Selected Items of Information and Their Disclosure in Annual Reports", The Accounting Review, Vol. 49, pp. 423-435.

Nicholls and Ahmed (1995) "Disclosure Quality of Corporate Annual Reports of Non-financial Companies in Bangladesh", Research in Accounting Emerging Economics, Vol.3 pp. 149-170

Wallace (1988a) "Corporate Financial reporting in Nigeria", Accounting and Business Research, Vol. 18, No. 72, pp. 352-362.

How to Cite: Siddique MA, Neogy TK and Islam MR. 2014. Variations in Opinions toward Disclosure Trend of Insurance Companies in Bangladesh: An Empirical Study American Journal of Trade and Policy, $1,42-50$.

Source of Support: Nil, Conflict of Interest: None declared.

\section{Appendix-1}

Table 1: Showing the opinions of respondents regarding the use of annual reports for decision making

\begin{tabular}{|c|c|c|c|c|c|}
\hline \multirow[t]{2}{*}{ Opinion } & & \multicolumn{2}{|c|}{ Investors } & \multirow{2}{*}{$\begin{array}{l}\text { Professional } \\
\text { Accountants }\end{array}$} & \multirow[t]{2}{*}{ Total } \\
\hline & & Businessmen & Academician & & \\
\hline \multirow{3}{*}{$\begin{array}{l}\text { Use of } \\
\text { annual report } \\
\text { for decision } \\
\text { making }\end{array}$} & Yes & $16(75 \%)$ & $18(90 \%)$ & $18(90 \%)$ & $52(87 \%)$ \\
\hline & No & $4(25 \%)$ & $2(10 \%)$ & $2(10 \%)$ & $8(13 \%)$ \\
\hline & Total & $20(100 \%)$ & $20(100 \%)$ & $20(100 \%)$ & $60(100 \%)$ \\
\hline
\end{tabular}

Table 1.1: Chi-Square tests on the basis of Table 1

\begin{tabular}{lccc}
\hline & Value & df & Asymp. Sig. (2-sided) \\
\hline Pearson Chi-Square & $1.154(\mathrm{a})$ & 2 & 0.562 \\
Likelihood Ratio & 1.098 & 2 & 0.577 \\
N of Valid Cases & 60 & &
\end{tabular}

(a) 3 cells ( $50.0 \%$ ) have expected count less than 5 . The minimum expected count is 2.67
Table 2: Showing the opinions of respondents regarding the adequacy of disclosure

\begin{tabular}{|c|c|c|c|c|c|}
\hline \multirow[t]{2}{*}{ Opinion } & & \multicolumn{2}{|c|}{ Investors } & \multirow{2}{*}{$\begin{array}{l}\text { Professional } \\
\text { Accountants }\end{array}$} & \multirow[t]{2}{*}{ Total } \\
\hline & & Businessmen & Academician & & \\
\hline \multirow[t]{3}{*}{ Adequacy } & Yes & $10(50 \%)$ & $8(40 \%)$ & $14(70 \%)$ & $32(53 \%)$ \\
\hline & No & $10(50 \%)$ & $12(60 \%)$ & $6(30 \%)$ & $28(47 \%)$ \\
\hline & Total & $20(100 \%)$ & $20(100 \%)$ & $20(100 \%)$ & $60(100 \%)$ \\
\hline
\end{tabular}

Source: Opinion Survey Reports

Table 2.1: Chi-Square tests on the basis of Table 2

\begin{tabular}{lccc}
\hline & Value & df & Asymp. Sig. (2-sided) \\
\hline Pearson Chi-Square & $3.750(a)$ & 2 & 0.153 \\
Likelihood Ratio & 3.830 & 2 & 0.147 \\
No of Valid Cases & 60 & & \\
\hline
\end{tabular}

(a) 0 cells $(0.0 \%)$ have expected count less than 5 . The minimum expected count is 9.33 
Table 3: Showing the opinions of respondents regarding the reliability of information in annual reports

\begin{tabular}{|c|c|c|c|c|c|}
\hline \multirow[t]{2}{*}{ Opinion } & & \multicolumn{2}{|c|}{ Investors } & \multirow{2}{*}{$\begin{array}{l}\text { Professional } \\
\text { Accountants }\end{array}$} & \multirow[t]{2}{*}{ Total } \\
\hline & & Businessmen & Academician & & \\
\hline \multirow[t]{3}{*}{ Reliability } & Yes & $12(60 \%)$ & $11(55 \%)$ & $18(90 \%)$ & $41(68 \%)$ \\
\hline & No & $8(40 \%)$ & $9(45 \%)$ & $2(10 \%)$ & $19(32 \%)$ \\
\hline & Total & $20(100 \%)$ & $20(100 \%)$ & $20(100 \%)$ & $60(100 \%)$ \\
\hline
\end{tabular}

Source: Opinion Survey Reports

Table 3.1: Chi-Square tests on the basis of Table 3

\begin{tabular}{lccc}
\hline & Value & df & Asymp. Sig. (2-sided) \\
\hline Pearson Chi-Square & $6.624(\mathrm{a})$ & 2 & 0.036 \\
Likelihood Ratio & 7.470 & 2 & 0.024 \\
N of valid cases & 60 & & \\
\hline
\end{tabular}

(a) 0 cells $(0.0 \%)$ have expected count less than 5 . The minimum expected count is 6.33

Table 4: Showing the opinions of the respondents regarding the consistency of information in annual reports

\begin{tabular}{lccccc}
\hline Opinion & \multicolumn{2}{c}{ Investors } & Professional & Total \\
\cline { 2 - 5 } & & Businessmen & Academician & Accountants & \\
\hline Consistency & Yes & $12(60 \%)$ & $14(70 \%)$ & $17(85 \%)$ & $43(72 \%)$ \\
& No & $8(40 \%)$ & $6(30 \%)$ & $3(15 \%)$ & $17(28 \%)$ \\
& Total & $20(100 \%)$ & $20(100 \%)$ & $20(100 \%)$ & $60(100 \%)$ \\
\hline
\end{tabular}

Source: Opinion Survey Reports

Table 4.1: Chi-Square tests on the basis of Table 4

\begin{tabular}{lccc}
\hline & Value & df & Asymp. Sig. (2-sided) \\
\hline Pearson Chi-Square & $3.119(\mathrm{a})$ & 2 & 0.210 \\
Likelihood Ratio & 3.265 & 2 & 0.195 \\
N of valid cases & 60 & & \\
\hline
\end{tabular}

(a) 0 cells $(0.0 \%)$ have expected count less than 5 . The minimum expected count is 5.67

Table 5: Showing the opinions of the respondents regarding the Comparability of information's in annual reports

\begin{tabular}{|c|c|c|c|c|c|}
\hline \multirow{2}{*}{\multicolumn{2}{|c|}{ Opinion }} & \multicolumn{2}{|c|}{ Investors } & \multirow{2}{*}{$\begin{array}{l}\text { Professional } \\
\text { Accountants }\end{array}$} & \multirow[t]{2}{*}{ Total } \\
\hline & & Businessmen & Academician & & \\
\hline \multirow[t]{3}{*}{ Comparability } & Yes & $10(50 \%)$ & $14(70 \%)$ & $18(90 \%)$ & $42(70 \%)$ \\
\hline & No & $10(50 \%)$ & $6(30 \%)$ & $2(10 \%)$ & $18(30 \%)$ \\
\hline & Total & $20(100 \%)$ & $20(100 \%)$ & $20(100 \%)$ & $60(100 \%)$ \\
\hline
\end{tabular}

Source: Opinion Survey Reports

Table 5.1: Chi-Square Tests on the basis of Table 5

\begin{tabular}{lccc}
\hline & Value & df & Asymp. Sig. (2-sided) \\
\hline Pearson Chi-Square & $7.619(a)$ & 2 & 0.022 \\
Likelihood Ratio & 8.140 & 2 & 0.017 \\
$N$ of valid cases & 60 & & \\
\hline
\end{tabular}

(a) 0 cells $(0.0 \%)$ have expected count less than 5 . The minimum expected count is 6.00
Table 6: Showing the opinions of the respondents regarding the relevance of information in annual reports

\begin{tabular}{|c|c|c|c|c|c|}
\hline \multirow[t]{2}{*}{ Opinion } & & \multicolumn{2}{|c|}{ Investors } & \multirow{2}{*}{$\begin{array}{l}\text { Professional } \\
\text { Accountants }\end{array}$} & \multirow[t]{2}{*}{ Total } \\
\hline & & Businessmen & Academician & & \\
\hline \multirow[t]{3}{*}{ Relevancy } & Yes & $12(60 \%)$ & $14(70 \%)$ & $17(85 \%)$ & $43(72 \%)$ \\
\hline & No & $8(40 \%)$ & $6(30 \%)$ & $3(15 \%)$ & $17(28 \%)$ \\
\hline & Total & 20 (100\%) & 20 (100\%) & 20 (100\%) & $60(100 \%)$ \\
\hline
\end{tabular}

Source: Opinion Survey Reports

Table 6.1: Chi-Square tests on the basis of Table 6

\begin{tabular}{lccc}
\hline & Value & df & Asymp. Sig. (2-sided) \\
\hline Pearson Chi-Square & $3.119(\mathrm{a})$ & 2 & 0.210 \\
Likelihood Ratio & 3.265 & 2 & 0.195 \\
N of valid cases & 60 & & \\
\hline
\end{tabular}

(a) 0 cells $(0.0 \%)$ have expected count less than 5 . The minimum expected count is 5.67

Table 7: Showing the opinions of the respondents regarding the satisfaction of information in annual reports

\begin{tabular}{|c|c|c|c|c|c|}
\hline \multirow{2}{*}{\multicolumn{2}{|c|}{ Opinion }} & \multicolumn{2}{|c|}{ Investors } & \multirow{2}{*}{$\begin{array}{l}\text { Professional } \\
\text { Accountants }\end{array}$} & \multirow[t]{2}{*}{ Total } \\
\hline & & Businessmen & Academician & & \\
\hline \multirow[t]{3}{*}{ Satisfaction } & Yes & $7(35 \%)$ & $8(40 \%)$ & $10(50 \%)$ & $25(42 \%)$ \\
\hline & No & $13(65 \%)$ & $12(60 \%)$ & $10(50 \%)$ & $35(58 \%)$ \\
\hline & Total & $20(100 \%)$ & 20 (100\%) & 20 (100\%) & $60(100 \%)$ \\
\hline
\end{tabular}

Source: Opinion Survey Reports

Table 7.1: Chi-Square tests on the basis of Table 7

\begin{tabular}{lccc}
\hline & Value & df & Asymp. Sig. (2-sided) \\
\hline Pearson Chi-Square & $0.960(\mathrm{a})$ & 2 & 0.619 \\
Likelihood Ratio & 0.959 & 2 & 0.619 \\
$\mathrm{~N}$ of valid cases & 60 & & \\
\hline
\end{tabular}

(a) 0 cells $(0.0 \%)$ have expected count less than 5 . The minimum expected count is 8.33

Table 8: Showing the opinions of the respondents regarding the compliance of BASs in preparing annual reports

\begin{tabular}{llcccc}
\hline Opinion & \multicolumn{2}{c}{ Investors } & Professional & Total \\
\cline { 2 - 4 } & & Businessmen & Academician & Accountants & \\
\hline Compliance & Yes & $16(80 \%)$ & $15(75 \%)$ & $20(100 \%)$ & $51(85 \%)$ \\
of IASs & No & $4(20 \%)$ & $5(25 \%)$ & $0(0 \%)$ & $9(15 \%)$ \\
& Total & $20(100 \%)$ & $20(100 \%)$ & $20(100 \%)$ & $60(100 \%)$ \\
\hline
\end{tabular}

Source: Opinion Survey Reports

Table 8.1: Chi-Square tests on the basis of Table 8

\begin{tabular}{lccc}
\hline & Value & df & Asymp. Sig. (2-sided) \\
\hline Pearson Chi-Square & $5.490(\mathrm{a})$ & 2 & 0.064 \\
Likelihood Ratio & 8.216 & 2 & 0.016 \\
$\mathrm{~N}$ of valid cases & 60 & & \\
\hline
\end{tabular}

(a) 3 cells $(50.0 \%)$ have expected count less than 5 . The minimum expected count is 3.00 


\section{Apendix-2}

\section{Questionnaire (For Professional Accountant) \\ Part-A}

1. Name of the professional accountant.

2. Name of the firm.

3. Experience of auditor.

\section{Part-B}

1. Do you use financial reports as a basis for decision making?

$\square$ Yes $\quad \square$ No

2. For what purpose(s) do you use financial reports?

(Please tick as many boxes as are relevant to you)

$\square$ For reading and academic interest

$\square$ For deciding about holding or selling shares in your private capacity

$\square$ To decide buying, holding or selling shares in your professional capacity.

$\square$ To make decisions on behalf of clients or employer

$\square$ To exercise discretion as a government official

$\square$ To advice clients

$\square$ Other (Please specify)

3. Do you think that the insurance company's annual reports contain adequate information necessary to serve your purpose of using them?

$\square$ Yes $\quad \square$ No

4. Do you think that the information provided by the insurance company's annual report that are reliable

$\square$ Yes $\quad \square$ No

5. Do you think that the annual reports of the insurance companies are consistent?

$\square$ Yes $\quad \square$ No

6. Do you think that the annual report of the insurance companies is comparable?

$\square$ Yes $\quad \square$ No

7. Do you think that the annual report of the insurance companies is readable?

$\square$ Yes $\quad \square$ No

8. Do you think that the information provided by the annual report of the insurance companies is relevant?

$\square$ Yes $\quad \square$ No

9. Do you think that disclosure policies of insurance company are satisfactory?

$\square$ Yes $\square$ No

10. Do you think that insurance companies follow our prescribed adopted standards of ICAB?

$\square$ Yes $\quad \square$ No

11. Do they follow the Insurance Companies Act 1938 as amended in 2008?

$\square$ Yes $\quad \square$ No

Thank You for your cooperation 


\section{Questionnaire (For Investors)}

Part-A

1. Name:

2. Profession:

3. Educational Qualifications:.

4. How long have you been involved in share market?. Years.

\section{Part-B}

5. Do you use financial reports as a basis for decision making?

$\square$ Yes

$\square$ No

6. For what purpose(s) do you use financial reports?

(Please tick as many boxes as are relevant to you)

$\square$ For reading and academic interest

$\square$ For deciding about holding or selling shares in your private capacity

$\square$ To decide buying, holding or selling shares in your professional capacity.

$\square$ make decisions on behalf of clients or employer

$\square$ To exercise discretion as a government official

$\square$ Other (Please specify)

7. Do you think that the insurance company annual reports that you use contain adequate information necessary to serve your purpose of using them?

$\square$ Yes $\square$ No

8. Do you think that the information provided by the insurance company's annual report that you use are reliable?

$\square$ Yes $\quad \square$ No

9. Do you think that the annual reports of the insurance companies are consistent?

$\square$ Yes $\square$ No

10. Do you think that the annual report of the insurance company is comparable?

$\square$ Yes $\quad \square$ No

11. Do you think that the annual report of the insurance companies is readable?

$\square$ Yes $\quad \square$ No

12. Do you think that the information provided by the annual report of the insurance companies is relevant?

$\square$ Yes $\quad \square$ No

13. Should the following be disclosed in the insurance companies' revenue account separately?

(a) Premium less reinsurance

$\square$ Yes $\square$ No

(b) Renewal premium

$\square$ Yes $\square$ No

(c) Group insurance

$\square$ Yes $\square$ No

(d) Interest, rent and dividend

$\square$ Yes $\square$ No 
(e) Profit on sale of share

$\square$ Yes $\square$ No

(f) Claims under policies

$\square$ Yes $\square$ No

(g) Expenses of management

$\square$ Yes $\square$ No

(h) Other income and expenses

$\square$ Yes $\square$ No

(i) Various deposits

$\square$ Yes $\square$ No

(i) Various loans and advances

$\square$ Yes $\square$ No

14. Do they follow the Insurance Companies Act 1938 as amended in 2008?

$\square$ Yes

$\square$ No

15. Do you think that disclosure policies of insurance company are satisfactory?

$\square$ Yes $\quad \square$ No

Thank You for your cooperation 